\title{
Is Exclusive Breastfeeding a Protective Factor Against Idiopathic Epilepsy?
}

\author{
IIlk Altı Ay Sadece Anne Sütü ile Beslenme Idiyopatik \\ Epilepsi Gelişiminde Koruyucu Bir Faktör mü?
}

\section{Özgün Araştirma Research Article}

\section{Pinar Arican $\odot$, Pinar Gencpinar $\odot$, Dilek Cavusoglu $\odot$, Nihal Olgac Dundar $\odot$}

\section{ABSTRACT}

Objective: In this study, we aimed to identify whether short-term exclusive breastfeeding is associated with development of epilepsy in children.

Method: Patients with idiopathic epilepsy who attended our outpatient clinic during the period from January 2017 to August 2017 were included in the study. Neurologically normal children, matched for age and sex, were considered as controls.

Results: A total of 102 patients and 102 controls were participated in this study. Exclusive breastfeeding rates in case and control groups were $58 \%$ and $82 \%$, respectively. The rate of exclusive breastfeeding within the first six months was significantly lower in the patient group relative to the control group ( $p=.001)$. (odds ratio 0.29 , confidence interval: 0.15-0.55).

Conclusion: Our study showed that short-term exclusive breastfeeding might be one of the risk factors for idiopathic epilepsy.

Keywords: Brain-derived neurotrophic factor, breast milk, child, idiopathic epilepsy, lactoferrin

Öz

Amaç: Bu çalışmada, çocuklarda kısa süreli anne sütüyle beslenmenin epilepsi gelişmesi ile ilişkili olup olmadığını belirlemeyi amaçladık.

Yöntem: Bu çalışmaya, Ocak 2017-Ağustos 2017 tarihleri arasında polikliniğimize başvuran idiyopatik epilepsi nedeni ile takipli hastalar dahil edildi. Kontrol grubu olarak nörolojik gelişimi normal, yaş ve cinsiyet açısından eşleştirilmiş çocuklar dahil edildi.

Bulgular: Çalışmaya 102 hasta ve 102 sağlıklı çocuk alındı. Ilk altı ay sadece anne sütü ile beslenme sıklığı hasta grubunda \%58, kontrol grubunda \%82 idi. ilk altı ay sadece anne sütü ile beslenme sıklığı hasta grubunda kontrol grubuna göre istatistiksel olarak anlamlı düşüktü ( $p=.000$ ) (Odds ratio 0,29, güven aralığı 0,15-0,55).

Sonuç: Çalışmamız, altı aydan kısa süreli anne sütü ile beslenmenin idiyopatik epilepsi için risk faktörlerinden biri olabileceğini göstermiştir.

Anahtar kelimeler: Beyin kaynaklı nörotrofik faktör, anne sütü, çocuk, idiyopatik epilepsi, laktoferrin
P. Arican 0000-0003-3990-7489 Izmir Tepecik Education and Research Hospital, Department of Pediatric Neurology Izmir, Turkey

N. Olgac Dundar 0000-0002-5902-3501 Izmir Katip Celebi University, Department of Pediatric Neurology, Izmir, Turkey

D. Cavusoglu 0000-0003-4924-5300 Afyon Kocatepe University, Department of Pediatric Neurology, Izmir, Turkey

Cite as: Arıcan P, Gencpinar P, Cavusoglu $D$, Olgac Dundar $N$. Is exclusive breastfeeding a protective factor against idiopathic epilepsy?. Tepecik Eğit. ve Araşt. Hast. Dergis 2020;30(1):62-5.
(C) Telif hakkı T.C. Sağık Bakanlığı izmir Tepecik Eğit. ve Araşt. Hastanesi. Logos Tıp Yayıncılık tarafindan yayınlanmaktadır. Bu dergide yayınlanan bütün makaleler Creative Commons Atff-GayriTicari 4.0 Uluslararası Lisansı ile lisanslanmıștır.

(c) Copyright Association of Publication of the T.C. Ministry of Health Izmir Tepecik Education and Research Hospital. This journal published by Logos Medical Publishing. Licenced by Creative Commons Attribution-NonCommercial 4.0 International (CC BY-NC 4.0) 


\section{INTRODUCTION}

Optimal nutrition in early life has positive effects on neurodevelopmental processes. The composition of breastmilk is the ideal norm for infant nutrition. Breastfeeding appears to be positively associated with cognitive performance of children ${ }^{(1-3)}$.

Excitatory/inhibitory synaptic imbalance is believed to be the underlying mechanism of epileptogenesis, however there is only limited knowledge of what causes the imbalance of excitation and inhibition of the neuronal network. Preclinical studies suggest that epileptogenesis can overlap with the mechanisms underlying the inflammatory response and neuronal plasticity ${ }^{(4,5)}$.

Due to its essential nutrient components, receiving exclusive breastfeeding for less than six months may be associated with idiopathic epilepsy. In this study, we aimed to identify whether short-term exclusive breastfeeding was associated with development of epilepsy in children.

\section{MATERIAL and METHODS}

This case-control study was conducted at the outpatient clinic during the period from January 2017 to August 2017. Patients with two or more unprovoked seizures occurring at intervals longer than 24 hours were considered to have epilepsy. Idiopathic epilepsy is defined as epilepsy of predominately genetic or presumed genetic origin without any gross neuroanatomic or neuropathologic abnormality ${ }^{(6)}$. The approval of the local ethics committee was obtained.

The patients with idiopathic epilepsy between the ages of six months and 18 years who attended the clinic were included in the study. Children with cerebral palsy, structural brain abnormalities, posttraumatic epilepsy, congenital malformations, neurometabolic disorders and intracranial infections were excluded. Children who had a history of prenatal, natal or neonatal complications like prematurity, birth trauma were also excluded. Neurologically normal age-, and sex- matched children, matched were considered as controls.

The data on patients and controls were obtained with a prepared and structured questionnaire used in personal interviews with parents after receipt of informed consent. Details on the patient, history of epilepsy in the family, duration of breastfeeding, use of complementary foods and infant formula were included in the analysis.. Exclusive breastfeeding was defined as feeding the infant only with breast milk between the ages of 0-6 months in accordance with the recommendations of World Health Organization and the American Academy of Pediatrics ${ }^{(7)}$.

The demographic data and neuroimaging results of patients were then reviewed from the medical records. Cranial magnetic resonance imaging was performed in all patients to rule out the possible causes of epilepsy.

Statistical analysis was performed using Statistical Package for the Social Sciences software program version 21.0. Frequencies and percentages were calculated. Study subjects' ages were also described using mean \pm standard deviation. The chi-square test and Fisher's exact test were used for comparison between independent groups of categorical data. The odds ratio and its $95 \%$ confidence interval for certain risk factors of epilepsy were calculated. For all statistical tests, values of $p<.05$ (two-tailed) were considered statistically significant.

\section{RESULTS}

A total of 102 patients and 102 control subjects participated in this study. The case group consisted of 60 (59\%) male, and 42 (41\%) female patients, whereas control group comprised 61 (60\%) male, and 41 (40\%) female subjects. The mean ages of the pati- 
ents and the control subjects were $8 \pm 4$, and $8 \pm 4$ years, respectively. There were no significant intergroup differences in terms of sex and age of the participants ( $p>05)$.

Family history of epilepsy was found in 26 patients $(25 \%)$ in the case and 12 children (12\%) in the control group. Positive family history of epilepsy was significantly higher for patients as compared with controls ( $p=.019)$. Table 1 shows the participants' demographic data.

Table 1. Demographic data of the children with epilepsy and control group.

\begin{tabular}{lccc}
\hline & $\begin{array}{c}\text { Case group } \\
(\mathbf{n}=102)\end{array}$ & $\begin{array}{c}\text { Control group } \\
(\mathbf{n}=102)\end{array}$ & $\mathbf{p}$ \\
\hline Gender, $\mathrm{n}(\%)$ & & & \\
$\begin{array}{l}\text { Male } \\
\text { Female }\end{array}$ & $60(59 \%)$ & $61(60 \%)$ & .887 \\
$\begin{array}{l}\text { Age (years) } \\
\text { (meantstandard deviation) }\end{array}$ & $42(41 \%)$ & $41(40 \%)$ & \\
$\begin{array}{l}\text { Family history of epilepsy, } \mathrm{n}(\%) \\
\text { Yes }\end{array}$ & $8 \pm 4$ & $8 \pm 4$ & .952 \\
No & $26(25 \%)$ & $12(12 \%)$ & .019 \\
\hline & $76(75 \%)$ & $90(88 \%)$ & \\
\hline
\end{tabular}

Exclusive breastfeeding rates in case and control groups were $58 \%$ and $82 \%$, respectively. There was a significant difference between case and control groups ( $p=.001)$. The odds ratio for developing epilepsy was 0.29 (95\% Cl:0.15 to 0.55) (Table 2). We exclu-

Table 2. Comparison of exclusive breastfeeding rate between two groups.

\begin{tabular}{lcccc}
\hline & $\begin{array}{c}\text { Case } \\
\text { group } \\
(\mathbf{n = 1 0 2})\end{array}$ & $\begin{array}{c}\text { Control } \\
\text { group } \\
(\mathbf{n = 1 0 2 )}\end{array}$ & $\begin{array}{c}\text { OR } \\
(\mathbf{9 5 \%} \mathrm{Cl})\end{array}$ & $\begin{array}{c}\text { p } \\
\text { value }\end{array}$ \\
\hline Exclusive breastfeeding, n (\%) & & & & \\
Yes & $59(58 \%)$ & $84(82 \%)$ & 0.29 & .001 \\
No & $43(42 \%)$ & $18(18 \%)$ & $(0.15$ to 0.55$)$ &
\end{tabular}

Table 3. Comparison of exclusive breastfeeding rate between two groups without positive family history of epilepsy.

\begin{tabular}{lcccc}
\hline & $\begin{array}{c}\text { Case } \\
\text { group } \\
(\mathbf{n = 7 6 )}\end{array}$ & $\begin{array}{c}\text { Control } \\
\text { group } \\
(\mathbf{n = 9 0 )}\end{array}$ & $\begin{array}{c}\text { OR } \\
(\mathbf{9 5 \%} \mathrm{Cl})\end{array}$ & $\begin{array}{c}\mathbf{p} \\
\text { value }\end{array}$ \\
\hline $\begin{array}{l}\text { Exclusive breastfeeding, n (\%) } \\
\text { Yes }\end{array}$ & $43(57 \%)$ & $75(83 \%)$ & 0.26 & .001 \\
No & $33(43 \%)$ & $15(17 \%)$ & $(0.12$ to 0.53$)$ & \\
& & & & \\
\hline
\end{tabular}

ded children with positive family history of epilepsy as a subgroup analysis. Exclusive breastfeeding rates in the case and control groups were $57 \%$ and $83 \%$, respectively. The exclusive breastfeeding rate in the control group was significantly higher than in the case group ( $p=.001)$. The odds ratio for developing epilepsy was 0.26 (95\% Cl:0.12 to 0.53) (Table 3). Exclusive breastfeeding significantly reduces the risk of developing epilepsy.

\section{DISCUSSION}

Our results showed that exclusive breastfeeding rate was significantly higher for controls as compared with patients even if we excluded children with positive family history of epilepsy. Breast milk contains essential nutrient components, such as long-chain polyunsaturated fatty acids (LCPUFAs), cholesterol, and gangliosides. The presence of LCPUFAs in breastmilk, plays an important role in the early brain development. Arachidonic acid and docosahexaenoic acid are the major LCPUFAs in the membranes of brain cells that are abundant in breast milk until the infant is four to six months of age ${ }^{(8)}$. LCPUFAs accumulate in the brain and retina during the last trimester of pregnancy and the first months after birth (9). Docosahexaenoic acid has roles in regulating gene expression, ion channel activities, and can be further metabolized to neuroprotective metabolites in the brain ${ }^{(10)}$. LCPUFAs in breast milk may have protective effect against epilepsy. Moreover, breast milk contains brain-derived neurotrophic factor (BDNF) and lactoferrin. BDNF is a vital trophic protein for development and maintenance of the nervous system and essential to molecular mechanisms of synaptic plasticity ${ }^{(11,12)}$. In experimental models it has been shown that lactoferrin reduced hypoxia-ischemia induced modifications of the cortical metabolism and altered white matter microstructure as revealed in lactoferrin-supplemented rats. Lactoferrin has neuroprotective effects on recovery of brain metabolism, cerebral gray and white matter ${ }^{(13,14)}$. Presence of BDNF and lactoferrin in breast milk may also exert 
neuroprotective and anti-epileptogenic effects.

Asadi-Pooya et al. ${ }^{(15)}$ reported that breast-feeding did not demonstrate protective effect against development of epilepsy. In their study, they examined the relationship between epilepsy and history of breastfeeding however they didn't determine the role of exclusive breastfeeding. To the best of our knowledge, this study is the first to evaluate an association between exclusive breastfeeding and idiopathic epilepsy in the absence of possible risk factors, which emphasizes that more researches should be performed in this area. There are two reports in the literature supporting the role of exclusive breastfeeding against epilepsy ${ }^{(16,17)}$. In these studies, they included children with diagnosis of epilepsy due to different etiologies such as structural brain abnormalities, and prematurity. To avoid potential attrition bias in our study, we included children diagnosed with idiopathic epilepsy cerebral palsy, structural brain abnormalities, posttraumatic epilepsy, congenital malformations, neurometabolic disorders, intracranial infections and history of prenatal, natal or neonatal complications were excluded.

Our study showed that short-term exclusive breastfeeding could be one of the risk factors for developing epilepsy. Considering the benefits of breast milk, infants should be breastfed exclusively for the first six months of life.

Ethics Committee Approval: Approval was obtained from the İzmir Katip Çelebi University NonInterventional Clinical Research Ethics Committee (02.11.2016/271).

Conflict of Interest: The authors declare that they have no conflict of interest.

Funding: The authors received no financial support for the research, authorship, and or publication of this article.

Informed Consent: Informed consent was obtained.

\section{REFERENCES}

1. Belkind-Gerson J, Carreón-Rodríguez A, Contreras-Ochoa CO, Estrada-Mondaca S, Parra-Cabrera MS. Fatty acids and neurodevelopment.J Pediatr Gastroenterol Nutr. 2008;47:7-9. [CrossRef]

2. Stam J, Sauer PJ, Boehm G. Can we define an infant's need from the composition of human milk? Am J Clin Nutr. 2013;98:521-8. [CrossRef]

3. Nyaradi A, Li J, Hickling S, Foster J, Oddy WH. The role of nutrition in children's neurocognitive development, from pregnancy through childhood. Front Hum Neurosci. 2013;26:97. [CrossRef]

4. Becker AJ. Animal models of acquired epilepsy: insights into mechanisms of human epileptogenesis. Neuropathol Appl Neurobiol. 2017. [CrossRef]

5. Ye H, Kaszuba S. Inhibitory or excitatory? Optogenetic interrogation of the functional roles of GABAergic interneurons in epileptogenesis. J Biomed Sci. 2017;24:93. [CrossRef]

6. Shorvon SD. The etiologic classification of epilepsy. Epilepsia. 2011;52:1052-7. [CrossRef]

7. Eidelman Al, Schanler RJ, Johnston $M$, et al. Breastfeeding and the use of human milk. Pediatrics. 2012;12:827-41.

8. Xiang $M$, Alfven $G$, Blennow $M$, Trygg $M$, Zetterström R. Long-chain polyunsaturated fatty acids in human milk and brain growth during early infancy. Acta Paediatr. 2000;89:142-7. [CrossRef]

9. Koletzko B, Agostoni C, Carlson SE, et al. Long chain polyunsaturated fatty acids (LC-PUFA) and perinatal development. Acta Paediatr. 2001;90:460-4. [CrossRef]

10. Innis SM. Dietary (n-3) fatty acids and brain development. J Nutr. 2007;137:855-9. [CrossRef]

11. Ismail AM, Babers GM, El Rehany MA. Brain-Derived Neurotrophic Factor in Sera of Breastfed Epileptic Infants and in Breastmilk of Their Mothers. Breastfeed Med. 2015;10:277-82. [CrossRef]

12. Nassar MF, Younis NT, El-Arab SE, Fawzi FA. Neuro-developmental outcome and brain-derived neurotrophic factor level in relation to feeding practice in early infancy. Matern Child Nutr. 2011;7:188-97. [CrossRef]

13. Looij $Y$, Ginet $V$, Chatagner A, et al. Lactoferrin during lactation protects the immature hypoxic-ischemic rat brain. Ann Clin Transl Neurol. 2014;1:955-67. [CrossRef]

14. Ginet V, van de Looij $Y$, Petrenko V, et al. Lactoferrin during lactation reduces lipopolysaccharide-induced brain injury. Biofactors. 2016;42:323-36.

15. Asadi-Pooya AA, Hojabri K. Risk factors for childhood epilepsy: a case-control study. Epilepsy Behav. 2005;6:203-6. [CrossRef]

16. Sun Y, Vestergaard M, Christensen J, Olsen J. Breastfeeding and risk of epilepsy in childhood: a birth cohort study. J Pediatr. 2011;158:924-9. [CrossRef]

17. Whitehead E, Dodds L, Joseph KS, et al. Relation of pregnancy and neonatal factors to subsequent development of childhood epilepsy: a population based cohort study. Pediatrics. 2006;117:1298-1306. [CrossRef] 